\title{
Exploring the eligibility criteria of the child support grant and its impact on poverty
}

\author{
Rochelle Beukes, Ada Jansen, Mariana Moses and Derek Yu
}

\begin{abstract}
One of the most important policy objectives in the post-apartheid South African economy is to reduce poverty. Although economic growth and job creation are the preferred sources of alleviating poverty and inequality, social grant spending has contributed significantly to reduce poverty (Van der Berg et al. in Poverty trends since the transition: what we know. Stellenbosch Economic Working Papers: 19/09. Stellenbosch: Stellenbosch University, 2009). Recently proposals were tabled by the Department of Social Development of South Africa (Fin24 in R3.3bn plan to extend child support grant to 21. www.fin24.com/Economy/R33bn-child-care-grant-extension-to-21-on-cards-20150316.

Accessed August 7, 2015, 2015) to extend the age eligibility of the child support grant (CSG) to 21 years (at the time of writing children aged up to 18 years are eligible). This sparked an interest to investigate the impact on poverty of changes to the eligibility criteria of CSG, as well as its fiscal implications. Using person and household data from the 2010/2011 Income and Expenditure Survey, various simulations are performed to assess the impact on poverty rates and changes to social spending, given the following changes: (1) if all age-eligible children applied; (2) if all beneficiaries received the grant amount for the full 12-month duration; (3) if the age eligibility criterion is extended; and (4) if the monthly child grant income amount is revised upwards. We also examine how changes in the eligibility criteria affect the income distribution.
\end{abstract}

\section{Introduction}

African countries are generally associated with high levels of poverty and inequality (World Bank 2013), and governments of some countries (such as Ghana, Kenya, Lesotho, Mozambique, Namibia and South Africa) have implemented various poverty-reduction policies, such as social grant systems (see Devereux 2007; Levine et al. 2011; Osei 2011; Omiolola and Kaniki 2014). Although economic growth and job creation are preferred mechanisms to address poverty and inequality in South Africa, social protection remains the focal priority of the post-apartheid government. In fact, social grant spending has contributed significantly to reduce poverty (Van der Berg et al. 2009; Leibbrandt et al. 2010, 2012). In particular, the old-age grant (OAG) and child support grant (CSG) are the two key drivers of poverty reduction. 
The CSG was introduced by the South African Department of Social Development in 1998, with the primary purpose of providing financial support to the beneficiaries in need (Republic of South Africa 2015). Since its inception various revisions have been made to the age and income eligibility criteria. Recently, proposals to extend the age eligibility to 21 years (currently children up to 18 years are eligible) have been made. The question arises whether changes to the eligibility criteria can effectively reduce poverty and the fiscal implications they entail. Most of the existing local studies examined the impact of social grants on poverty by calculating the poverty indices with and without social grant income and decomposing poverty and inequality by income source. Other local studies simply investigated the extent to which eligible households did not receive social grants. These studies hardly investigated the impact on poverty by altering the eligibility criteria of these grants, given the proposals mentioned above. We focus explicitly on the poverty and fiscal implications of changing the CSG eligibility criteria. This is a relevant investigation in the South African context as changing the eligibility criteria has fiscal consequences (for example, extending the eligible age is associated with higher social spending); hence it is crucial to determine the most cost-effective option to reduce poverty.

We conduct various simulations on the eligibility of the CSG, namely (1) assuming all ageeligible children applied for the grant; (2) all beneficiaries received the grant amount for the full 12-month duration; (3) extending the age eligibility criterion; and (4) revising the monthly grant amount. The rest of the paper is structured as follows: Sect. 2 provides an overview of the CSG and some descriptive statistics. Section 3 reviews the results of existing local and international studies that investigated the impact of social grants (in particular CSG) on poverty incidence. Section 4 commences with an explanation of the different simulations on the eligibility criteria as well as the monthly CSG amount paid to beneficiaries, before we estimate the poverty incidence and the fiscal impact thereof. Section 5 concludes the study.

\section{Overview of the CSG}

The CSG provides financial assistance to poor families raising children. It is a monthly income support system to children younger than 18 years, paid to their caregivers (Black Sash 2015). The CSG is currently paid to parents or primary caregivers who either hold South African citizenship, permanent residence or refugee status. In the 2015/2016 fiscal year, the monthly grant amount is 330 South African Rands (R) per month (equivalent to approximately US $\left.\$ 23 \cdot 5^{1}\right)$.

Table 1 shows that the age eligibility criterion has gradually increased over the past decades. Prior to 2003, grants were initially paid to caregivers with children younger than 7 years; this has been extended up to 18 years since 2012. The CSG monthly amount started at a low nominal value of R100; from 2001/2002 to 2015/2016, the increase in the monthly grant amount varied between R10 and R30. Real monthly grant values (in 2011 March prices) declined from 1999 to 2001, before steadily rising to R261 in 2006. It

\footnotetext{
${ }^{1}$ Based on the Rand/US\$ exchange rate in 2016 May: R15.5 per US\$1.
} 
stabilised in the R250-270 range in subsequent years, before increasing to R275 in 2015 (see Fig. 1).

The number of CSG child beneficiaries has increased substantially since its inception: in 1998 the total was 34,471, which pale in comparison to the millions receiving it since 2001. In 2012 there were approximately 11.3 million beneficiaries. These increases can possibly be ascribed to broader media coverage by human rights groups and relaxation of the age eligibility criterion, enabling a greater proportion of the poor to gain access to these grants.

The means test is a measure that the South African Social Security Agency (SASSA) employs to assess the financial status of grant applicants. Before issuing the grant, they evaluate the income and asset level of the applicant to ensure that it does not exceed the stipulated income threshold. In the years preceding 2008 the means test criterion favoured the rural and informal settlement dwellers if they earned less than R13 200 per year, while urban dwellers received the grant if earning less than R9 600 per year (Van der Berg et al. 2010).

The income criterion was amended during the 2008/2009 fiscal year by removing the rural/urban distinction. Grants were awarded to a single person with an annual income threshold of R27 600 (R55 200 for married persons) as at 1 October 2008 (SASSA 2010). At the time of the Income Expenditure Survey (IES) 2010/2011 (the data source to be used in this study), married caregivers could qualify for a grant provided they jointly earned no more than R60 ooo per year, while the corresponding threshold for single caregivers was R30 ooo (SASSA 2010). The 2015/2016 means threshold for married grant applicants is R79 200 per year and for single caregivers it is R39 600 (Black Sash 2015).

The CSG accounts for a high proportion of total income for the poorer households. This is indicated in Fig. 2, where households are divided into deciles based on their per capita income. In particular, the CSG income represents 59 and $33 \%$ of total income for the first and second deciles, respectively.

\section{Results of Past Studies on the Effectiveness of Social Transfers}

The impact of social grants on poverty and inequality is well documented, particularly in the case of South Africa. Bhorat et al. (2014) evaluated the impact of the provision of social grants on household poverty and inequality, using the Income and Expenditure Survey (IES)2 1995 and 2005/2006 data. They found that access to social grant income was not limited to the poorest income deciles, although it contributed significantly to the total household income of the lowest three deciles. The impact on inequality though, is negligible (Bhorat et al. 2014: 230-233).

\footnotetext{
${ }^{2}$ IES takes place every 5 years, primarily capturing household income and expenditure information. Since the advent of democracy in 1994, four IESs (1995, 2000, 2005/2006 and 2010/2011) have been released. See Sect. 4 for more details.
} 
Table 1 Age eligibility, value and beneficiaries of child support grant Source: National Treasury, Budget Review (Various issues), Van der Berg et al. (2010), Hall (2014) and Statistics South Africa (2015)

\begin{tabular}{llllc}
\hline $\begin{array}{l}\text { Fiscal } \\
\text { year }\end{array}$ & $\begin{array}{l}\text { Eligible age } \\
\text { (years) }\end{array}$ & $\begin{array}{l}\text { Amount per month on April 1 } \\
\text { (nominal values) }\end{array}$ & $\begin{array}{l}\text { Amount per month (2011 } \\
\text { March prices) }\end{array}$ & $\begin{array}{l}\text { Number of } \\
\text { beneficiaries }\end{array}$ \\
\hline $1998 / 1999$ & $0-6$ & 100 & 206 & 34,471 \\
$1999 / 2000$ & $0-6$ & 100 & 191 & 352,617 \\
$2000 / 2001$ & $0-6$ & 100 & 183 & 974,724 \\
$2001 / 2002$ & $0-6$ & 110 & 189 & $1,907,774$ \\
$2002 / 2003$ & $0-6$ & 140 & 224 & $2,630,826$ \\
$2003 / 2004$ & $0-8$ & 160 & 236 & $4,309,772$ \\
$2004 / 2005$ & $0-10$ & 170 & 249 & $5,663,647$ \\
$2005 / 2006$ & $0-13$ & 180 & 256 & $7,075,266$ \\
$2006 / 2007$ & $0-13$ & 190 & 261 & $7,863,841$ \\
$2007 / 2008$ & $0-13$ & 200 & 257 & $8,189,975$ \\
$2008 / 2009$ & $0-13$ & 220 & 255 & $8,765,354$ \\
$2009 / 2010$ & $0-14$ & 240 & 257 & $9,570,287$ \\
$2010 / 2011$ & $0-14$ & 250 & 258 & $10,371,950$ \\
$2011 / 2012$ & $0-14$ & 270 & 269 & $10,927,731$ \\
$2012 / 2013$ & $0-17$ & 280 & 262 & $11,341,988$ \\
$2013 / 2014$ & $0-17$ & 290 & 259 & $11,125,946$ \\
$2014 / 2015$ & $0-17$ & 300 & 252 & Not available \\
$2015 / 2016$ & $0-17$ & 330 & 275 & yet \\
& & & & yot available \\
\hline
\end{tabular}

Two studies focused on estimating poverty indices with and without social grants. Leibbrandt et al. (2010) used the 2008 National Income Dynamics Study (NIDS)3 data to examine the impact of CSG and OAG on poverty reduction, and found that the poverty headcount ratio would have been $6 \%$ points higher without these two grants. Van der Berg et al. (2009) conducted a similar study using the IES 2005/2006 data; the results indicated that the poverty headcount ratio would have been $5 \%$ points higher by removing all social grant income.

Armstrong and Burger (2008) conducted poverty and inequality decompositions by income source using IES 2005/2006 data. Results showed that social grants as an income source caused the poverty headcount ratio and the squared poverty gap ratio to decrease by 4.7 and $23.1 \%$, respectively. However, grants were fairly ineffective in decreasing inequality because the wage income of high-income earners is the main driver of inequality. Leibbrandt et al. (2012) used the 2008 NIDS data to conduct inequality decomposition by income source and confirmed the results of Armstrong and Burger (2008).

\footnotetext{
${ }^{3}$ NIDS is a national panel data conducted by the Southern African Labour and Development Research Unit (SALDRU) at the University of Cape Town. The survey takes place every 2 years, and at the time of writing, four waves of data (2008, 2010, 2012 and 2014) have been released.
} 


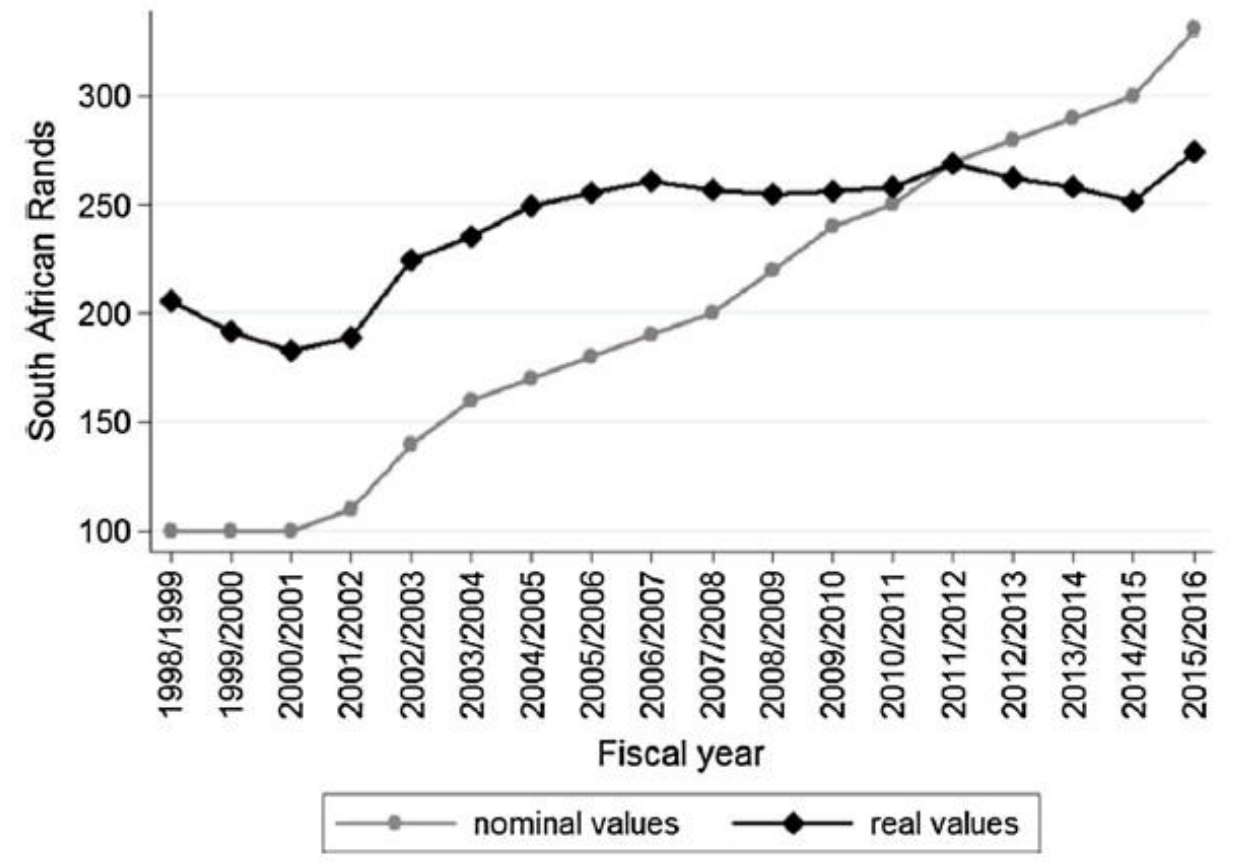

Fig. 1 Comparison of amounts received per month (nominal vs. real values). Source: Authors' own calculations 


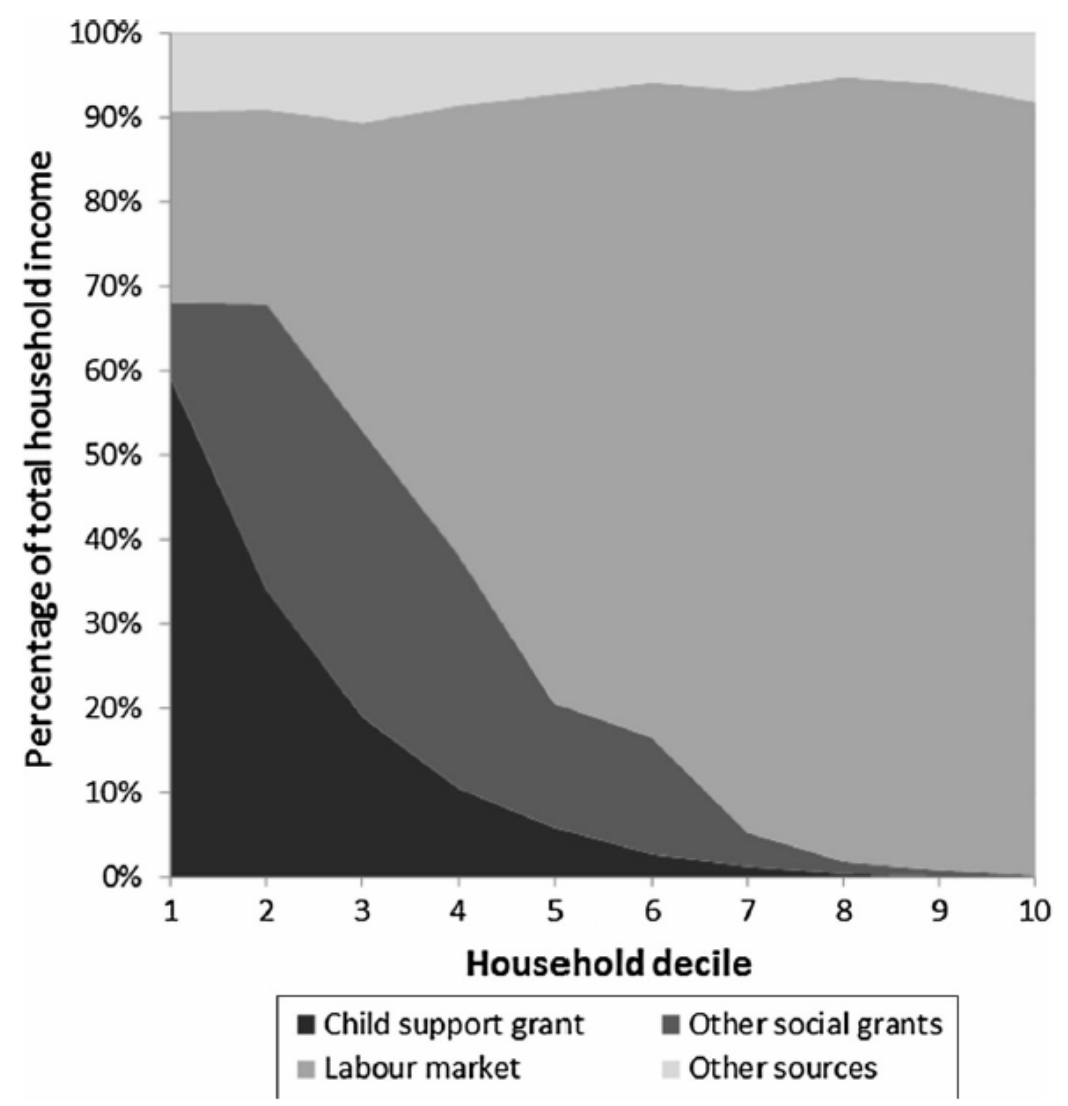

Fig. 2 Income source in each household decil. Source: Own calculations using the 2010/2011 income and expenditure survey data

Woolard et al. (2012), using the 2008 and 2010 NIDS data, focused specifically on access to the CSG. They found that more than $80 \%$ of households that received CSG income were in the lowest income quintile, and using a simulation exercise they showed that 3.2 million children who were eligible for the CSG did not receive it at all in 2010. In particular, infants and children aged 14-15 years were least likely to receive the grant income. Reasons stated by caregivers for either not applying or applying late included not having the documentation ready or perceiving their income being too high. Gomersall (2013) reported that the CSG reduced childhood poverty, increased access to schooling and enrolment rates, and improved hunger indicators (see Triegaardt 2005 as well as Case et al. 2005 for earlier studies supporting these results).

Four further studies investigated the impact of CSG on education, health and well-being. The study by Budlender and Woolard (2006) examined the impact of CSG (along with OAG) on school attendance. They found that the CSG was effective in improving school attendance amongst children who were direct grant beneficiaries. Children who did not receive the CSG were however more likely to attend schools if another child in the same household was a CSG recipient. Aguero et al. (2009) adopted the continuous treatment method to examine the impact of the CSG on child nutrition (measured by child heightfor-age) and found that the height of children who received the grant early in life was significantly improved. Coetzee (2013), using the 2008 NIDS data, examined the impact 
of CSG on child health, nutrition and education, and found that it had a significantly positive impact on all three indicators. A recent qualitative study by Wright et al. (2015) focused on the emotional wellbeing of female CSG recipients, who expressed both positive and negative experiences with respect to their dignity.

McEwen and Woolard (2008) used the 2008 NIDS data to conduct a simulation in which they identified the children who were eligible for the CSG, and then derived the proportion of eligible children who reported to have received CSG. They also simulated the number of children who would be eligible for the CSG in 2015 by assuming the following: an increase in the CSG monthly amount of $8 \%$ per annum in nominal terms, extending the eligible age from $0-13$ to $0-17$ years, and that the population would grow in accordance with the projections of the 2003 Actuarial Society of South Africa (ASSA) model. Given the results of these simulations, they estimated the total cost of CSG for every fiscal year from 2009/2010 to $2014 / 2015$. This study however did not examine the impact of changes in the eligibility criteria on poverty.

The existing local studies on the CSG confirm the significant impact of grants on poverty alleviation, as well as improving educational enrolment, health and nutrition. However, only one study examined the fiscal implications of changing the eligibility criteria and none of them investigated the impact on poverty. Governments generally face budget constraints; hence it is imperative to design a grant system that reduces poverty significantly and at the same time is cost-effective. This study contributes to the existing literature by addressing these aspects.

\section{Empirical Analysis}

4.1 Data and Methodology

We use the IES 2010/2011 person- and household-level data released by Statistics South Africa. The sampling frame was obtained from Statistics South Africa's Master Sample based on the 2011 Population Census enumeration areas. The Master Sample consisted of 3080 primary sampling units (PSUs), with more than 30,000 dwelling units being selected from these PSUs (Statistics South Africa 2012). Both the diary and recall methods were used (in the former case a 4-week diary was used; and a questionnaire for the recall method). Both methods were used for consumption data, while only the recall method was adopted to collect income data. In the case of the latter, income from various sources was captured (ranging from work and social grants, to pension and interests earned from investment). All income and consumption items were categorised using the Classification of Individual Consumption According to Purpose (COICOP) method.4 Only households that completed the questionnaire and at least two weekly diaries were included in the final sample of 25,328. Focusing on the data relating to the CSG, the household head had to report on the grant amount received. Each household member had to indicate whether they received the

\footnotetext{
${ }^{4}$ COICOP, adopted since IES 2005/2006, is a reference classification published by the United Nations Statistics Division that divides the purpose of individual consumption expenditures incurred by the following three institutional sectors: households, non-profit institutions serving households and general government.
} 
grant or not and the number of months for which they received the grant in the past 12 months. All income values were converted to March 2011 prices.

Several simulation exercises are performed to evaluate the implications of changes to the eligibility of the CSG criteria on poverty levels, as well as their fiscal impact. An important assumption is that there is no behavioural response as a result of the eligibility criterion changes, i.e. this is a static analysis. Note that this study uses the 2010/2011 IES data when the eligible age was $0-14$ years and the monthly grant amount was R250. Since then changes have been made to the eligibility criteria (refer to Table 1). Therefore, some of the simulations below reflect amendments that have already been made, for example, the age eligibility is currently $0-17$ years (which had already increased the fiscal budget on CSG).

The income variable inclusive of grant income is assumed to be the base variable, before the following simulations are conducted:

- We determine the effect on poverty levels had (1) all social grant income been removed and (2) only CSG income been removed, as well as the benefit to the fiscus of removing social transfers in both cases. These two simulation exercises are similar to the methodologies adopted in earlier studies (Van der Berg et al. 2009; Leibbrandt et al. 2010).

- The data on CSG included the total number of months household members had received the grant, based on the assumption that some households may have either erroneously under-reported or actually received less than 12 months of grant income. 5 Had these eligible households received the grant income for the full duration, social spending would have been higher and poverty levels lower. Hence, we derive total household income had the members received the CSG for the possible maximum number of months (12 months). This new income variable is used to re-estimate poverty levels.

- We look at the impact on poverty and the fiscus of extending the age eligibility to 17 and 21 years, respectively.

- A further analysis is to assess how the poverty levels change if the income criterion is removed.

- We run a simulation to assess the fiscal and poverty implications of increasing the monthly payment amount per child.

- We examine the impact of each simulation on inequality by calculating the Gini coefficients.

The changes in Foster-Greer-Thorbecke (FGT) poverty levels are estimated using the poverty line proposed by Woolard and Leibbrandt (2006), i.e. R3 864 per capita per annum in 2000 prices (R7175.52 in March 2011 prices). Since poverty rates may be influenced by the choice of poverty line, we complement the FGT poverty indices with cumulative density functions (CDFs).

\section{Results}

${ }^{5}$ According to Woolard et al. (2012), there have been cases of eligible households receiving the CSG for less than 12 months in the past year. 
Using the per capita income variable as reported by respondents (i.e. the base income variable), we determine the FGT poverty headcount ratios by race for the entire population. ${ }^{6}$ Table 2 shows that, using the poverty line indicated, $46.8 \%$ of the population were defined as poor.

In simulation (1a), we assume households do not receive any social grant transfers. Table 2 and Fig. 3 show that the poverty headcount ratios increase nationally, and for all races, compared to the base income variable. This supports the findings of previous studies (Van der Berg et al. 2009; Leibbrandt et al. 2010) that social transfers significantly reduce poverty in South Africa. A similar simulation exercise (1b-excluding only CSG) was conducted and we observe the same findings.

Table 3 expands on the poverty implications of these simulations and their additional cost to the fiscus. For simulations (1a) and (1b), the poverty headcount ratio would have increased by 6 and $2 \%$ points, respectively. This increases the number of poor people by 3.06 and 1.01 million in each case. For simulation (1b), more than $94 \%$ of the additional poor people are Blacks, compared to $84.4 \%$ in simulation (1a). In both cases, there is a decline in social spending of approximately R25 000 in per capita terms.

As previously indicated, some eligible respondents reported receiving the CSG for less than 12 months. In simulation (2) we determine the income gain had they received the CSG for the entire 12 months and calculate the poverty headcount ratios using the revised income variable. Comparing this result to the base income variable, we find that the national headcount ratio decreases by just above $2 \%$ points (from 0.4677 to 0.4462 ). Slightly more than 1 million people would have moved out of poverty of which $86.4 \%$ are Blacks. However, this would have increased social spending by R15 000 per capita.

Focusing on the age eligibility criterion of the CSG, Table 2 presents the poverty headcount ratios if children aged 15-17 years [simulation (3)] and 15-21 years [simulation (4)] receive the grant, holding the income criterion unchanged. Poverty headcount ratios decrease for all races. Nationally, the ratios decline to below 0.44 if the age eligibility criterion is adjusted. The number of people moving out of poverty in both simulations is greater than that of simulation (2), and the proportion of Blacks slightly higher $(87.5 \%$ in both cases). In contrast, the additional social spending is slightly lower (below R15 000 in per capita terms).

\footnotetext{
${ }^{6}$ Table 5 shows the poverty gap and squared poverty gap ratios for the full population, whereas Table 6 shows these two ratios and the poverty headcount ratios for the population aged $0-17$ years.
} 
Table 2 Poverty headcount ratios by race (poverty line: R7 175.52, 2011 March prices). Source Own calculations using IES 2010/11 data

\begin{tabular}{llllll}
\hline & All & Black & Coloured & Indian & White \\
\hline Base income variable & 0.4677 & 0.5495 & 0.2624 & 0.0813 & 0.0681 \\
Simulation (1a) & 0.5285 & 0.6142 & 0.3269 & 0.1334 & 0.0939 \\
Simulation (1b) & 0.4878 & 0.5734 & 0.2743 & 0.0813 & 0.0685 \\
Simulation (2) & 0.4462 & 0.5261 & 0.2405 & 0.0796 & 0.0582 \\
Simulation (3) & 0.4373 & 0.5159 & 0.2326 & 0.0782 & 0.5650 \\
Simulation (4) & 0.4244 & 0.5017 & 0.2179 & 0.0764 & 0.0537 \\
Simulation (5) & 0.4371 & 0.5156 & 0.2310 & 0.0796 & 0.0582 \\
Simulation (6) & 0.4185 & 0.4941 & 0.2165 & 0.0755 & 0.0574 \\
Simulation (7) & 0.3960 & 0.4678 & 0.2015 & 0.0687 & 0.0559 \\
Simulation (8) & 0.4449 & 0.5246 & 0.2388 & 0.0796 & 0.0582 \\
Simulation (9) & 0.4358 & 0.5143 & 0.2308 & 0.0785 & 0.0565 \\
Simulation (10) & 0.4229 & 0.5001 & 0.2162 & 0.0764 & 0.0537 \\
\hline
\end{tabular}

Simulation (1a): Assuming all social grant income is zero

Simulation (1b): Assuming CSG income is zero

Simulation (2): Assuming all eligible children receive the CSG income for the full 12-month duration

Simulation (3): 15-17 year-old also received CSG, holding income threshold unchanged

Simulation (4): 15-21 year-old also received CSG, holding income threshold unchanged

Simulation (5): Monthly CSG amount increases to R300, holding income and age criteria unchanged

Simulation (6): Monthly CSG amount increases to R400, holding income and age criteria unchanged

Simulation (7): Monthly CSG amount increases to R500, holding income and age criteria unchanged

Simulation (8): Children aged 0-14 years receive R250 per month, dropping income criterion

Simulation (9): Children aged 0-17 years receive R250 per month, dropping income criterion

Simulation (10): Children aged 0-21 years receive R250 per month, dropping income criterion 


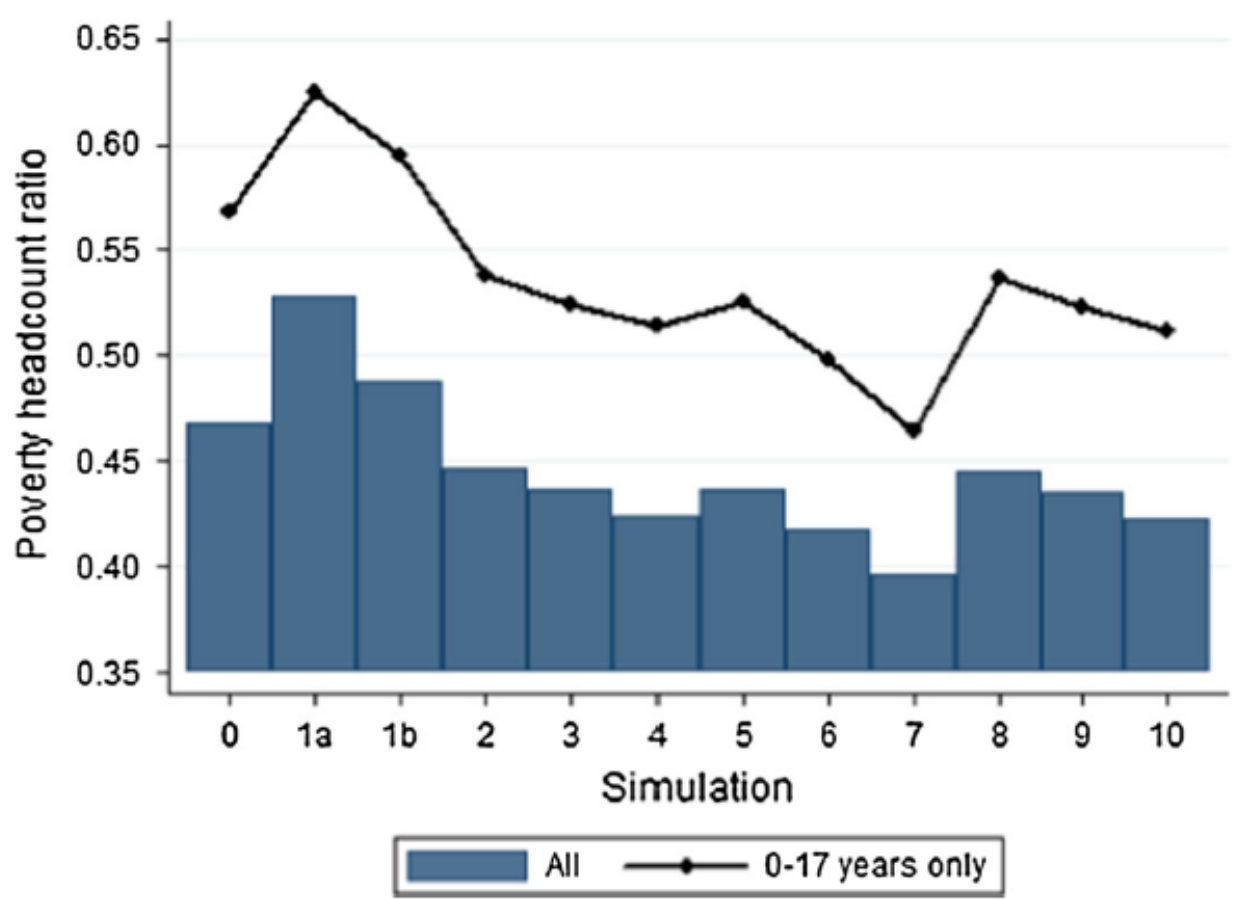

Fig. 3 Poverty headcount ratio in each simulation. Source: Own calculations using IES 2010/11 data

Table 3 Benefit and cost incidence. Source Own calculations using IES 2010/11 data

\begin{tabular}{|c|c|c|c|c|c|c|}
\hline Simulation & $\begin{array}{l}\text { Decrease in } \\
\text { poverty } \\
\text { headcount } \\
\text { ratio } \\
\text { (percentage } \\
\text { points) }\end{array}$ & $\begin{array}{l}\text { Number of } \\
\text { poor } \\
\text { people }\end{array}$ & $\begin{array}{l}\text { Decrease in } \\
\text { the number } \\
\text { of poor } \\
\text { people }\end{array}$ & $\begin{array}{l}\text { Black } \\
\text { share of } \\
\text { people } \\
\text { out of } \\
\text { poverty } \\
(\%)\end{array}$ & $\begin{array}{l}\text { Fiscal } \\
\text { implication/ } \\
\text { Additional total } \\
\text { cost (Rand } \\
\text { million, March } \\
2011 \text { prices) }\end{array}$ & $\begin{array}{l}\text { Per capita cost of } \\
\text { a change in the } \\
\text { number poor } \\
\text { people (Rand, } \\
\text { March } 2011 \\
\text { prices) }\end{array}$ \\
\hline (1a) & -6.08 & $26,641,932$ & $-3,062,940$ & $84.4^{\mathrm{a}}$ & $-76,822$ & $-25,081$ \\
\hline (1b) & -2.01 & $24,589,722$ & $-1,010,730$ & $94.5^{\mathrm{a}}$ & $-24,855$ & $-24,591$ \\
\hline (2) & 2.15 & $22,494,663$ & $1,084,329$ & 86.4 & 16,324 & 15,054 \\
\hline (3) & 3.04 & $22,042,481$ & $1,536,511$ & 87.5 & 22,960 & 14,943 \\
\hline (4) & 4.33 & $21,392,186$ & $2,186,806$ & 87.5 & 31,643 & 14,470 \\
\hline (5) & 3.06 & $22,033,407$ & $1,545,585$ & 87.7 & 22,505 & 14,561 \\
\hline (6) & 4.92 & $21,098,797$ & $2,480,195$ & 89.3 & 34,866 & 14,058 \\
\hline (7) & 7.17 & $19,963,049$ & $3,615,943$ & 90.4 & 47,228 & 13,061 \\
\hline (8) & 2.28 & $22,426,609$ & $1,152,383$ & 86.5 & 29,818 & 25,875 \\
\hline (9) & 3.19 & $21,970,394$ & $1,608,598$ & 87.5 & 39,188 & 24,362 \\
\hline (10) & 4.48 & $21,320,099$ & $2,258,893$ & 87.5 & 51,646 & 22,863 \\
\hline
\end{tabular}

Using the base income variable, the number of poor people was $23,578,992$

${ }^{\text {a }}$ For these simulations, this indicates the proportion of people moving into poverty who are blacks 
Simulations (5)-(7) assume changes to the monthly CSG amount, holding the income and age criteria constant. As we increase the monthly amount, the national poverty headcount ratio decreases to as low as 0.3960 for simulation (7)-a decrease of 0.0717 . The number of people moving out of poverty reaches a maximum of 3.62 million for this simulation, with the Black share also reaching as high as $90.4 \%$. As the monthly grant amount increases from simulations (5)-(7), the additional social cost per capita decreases to as low as R13 061.

In simulation (8) we maintain the age criterion and monthly amount but drop the income criterion; in simulations (9) and (10) we also adjust the age criterion. The national poverty headcount ratio drops by $2 \%$ points in simulation (8) compared to the base income variable (from 0.4677 to 0.4449 ). If we extend the eligible age to 17 and 21 years respectively [simulations (9) and (10)], the poverty headcount ratios drop by 3 and $4 \%$ points in each case. The number of people moving out of poverty nearly doubles from 1.15 million in simulation (8) to 2.26 million in simulation (10). The Black share of people out of poverty hovers around $87 \%$ in all three simulations. The additional social cost per capita exceeds R22 000 in all cases, which is considerably higher compared to simulations (2)-(7). Simulation (10) has a similar impact on poverty compared to simulation (4) but is more costly by approximately R20 billion (or R8 393 in per capita terms). Dropping the income criterion [simulation (10)] is therefore a more costly option to reduce poverty. Even though simulations (8)-(10) are most costly in per capita terms, dropping the means test would lead to a reduction in administrative costs (Black et al. 2015; Devereux et al. 2015).

Table 5 in the Appendix presents the poverty gap and squared poverty gap ratios of each simulation for the full population. A comparative analysis of all the simulations shows that simulation (7) results in the lowest poverty gap (0.1544) and squared poverty gap (0.0827) ratios. Figure 3 and Table 6 in the Appendix also show the three poverty ratios for each simulation compared to the base income variable ratios, for children aged $0-17$ years only. The results are similar to those for the entire population, that is, simulation (7) leads to the lowest poverty estimates. As the choice of a poverty line may influence these results, we conduct a sensitivity analyses by plotting the CDFs at different per capita income values for the various simulations (shown in Figs. 5, 6, 7 and 8 in the Appendix). For all simulations, results are robust regardless of the poverty line chosen.

In a broader context, Table 7 in the Appendix shows that simulations (2)-(10) increase CSG spending as proportion of total government expenditure 7 from the original $3.8 \%$ (before simulations) to between 5.7 and $9.6 \%$. This proportion is highest for simulations (7) and (10), at 9.1 and $9.6 \%$ respectively. These results are expected, given the additional total cost to the fiscus shown in Table 3. Social protection spending (which includes CSG) as proportion of total government spending, increases from $11.7 \%$ before simulations to as high as $17.0 \%$ in the case of simulation (10). These increased shares surpass those of the

\footnotetext{
7 To derive these proportions, we use information on government spending by function obtained from the Budget Review (National Treasury 2013) and the Estimates of National Expenditure (National Treasury 2014). In the table we assume total government spending increases by an equivalent amount to the increase in CSG spending, as a result of each simulation.
} 
corresponding health spending proportions. In the case of simulation 7 , for example, social protection increases to $15.8 \%$ of total government spending, compared to the health spending proportion of $11.9 \%$. Before any simulations, the education spending share $(21.3 \%)$ is almost twice the social protection spending share (11.7 \%). The difference in the proportional shares decreases to as low as $3.8 \%$ points in the case of simulation 10.

A deeper analysis of changes in the poverty status across the income distribution as a result of the simulations will better reflect the equity implications. In Table 4 households are divided into deciles using the base income variable (and as expected, the poor comes from the poorest four deciles). Each row shows the original decile location for people who have their poverty status changed as a result of the respective simulations. The results indicate that none of the people from decile 1 have their poverty status changed (i.e. they remain poor) in all simulations. Out of the 3.62 million people moving out of poverty after simulation (7), a mere $2.02 \%$ originated from decile 2 . If we consider decile 3 , once again simulation (7) has the biggest impact in terms of moving people out of poverty. For the richer deciles only simulation (1a) would cause some people in deciles 6-8 to move into poverty. In all other simulations, people in the richest five deciles remain above the poverty line.

Even though simulations (8)-(10) imply that the richer deciles would necessarily take up the CSG if the income criterion is removed, this may be not always be the case. The administrative burden associated with applying for the CSG is one of the factors which may prevent eligible people from accessing it (Rosa and Guthrie 2002: 3). Some rich households may take up the grant as a result of increased taxes when the income criterion is dropped. In the political economy literature (see Rosen and Gayer 2014), voters' preferences for public goods (where private substitutes exist) can be influenced by the link between public expenditure levels and the associated tax burden. If expenditure on public goods increases (which implies a higher tax burden), voters might switch from the consumption of private goods to public goods. It is therefore possible that wealthier households might take up the CSG when the income criterion is dropped.

We also calculate the Gini coefficients for each simulation and compare them to that of the base income variable (0.696). Figure 4 indicates that the removal of social grant income [i.e. simulations (1a) and (1b)] leads to a worsening of inequality; the Gini coefficient increases to 0.752 and 0.716 respectively. After changing the eligibility criteria, simulation (7) results in the lowest coefficient (0.659). Even though the Gini coefficients indicate an improvement in inequality for simulations (2)-(10), the decrease of the coefficient is not profound. These results support the findings of local studies (Armstrong and Burger 2008; Leibbrandt et al. 2012; Bhorat et al. 2014) that social grants do not significantly reduce inequality. 
Table 4 Change in poverty status by simulation. Source Own calculations using IES 2010/11 data

\begin{tabular}{|c|c|c|c|c|c|c|c|c|c|c|c|}
\hline & \multicolumn{11}{|c|}{ Household decile, using the base income variable } \\
\hline & 1 & 2 & 3 & 4 & 5 & 6 & 7 & 8 & 9 & 10 & \\
\hline Base income variable & 22.55 & 30.54 & 28.18 & 18.73 & 0.00 & 0.00 & 0.00 & 0.00 & 0.00 & 0.00 & 100 \\
\hline Simulation (1a) & 0.00 & 0.00 & 0.00 & 30.68 & 53.72 & 15.19 & 0.41 & 0.01 & 0.00 & 0.00 & 100 \\
\hline Simulation (1b) & 0.00 & 0.00 & 0.00 & 69.70 & 30.30 & 0.00 & 0.00 & 0.00 & 0.00 & 0.00 & 100 \\
\hline Simulation (2) & 0.00 & 0.00 & 0.86 & 99.14 & 0.00 & 0.00 & 0.00 & 0.00 & 0.00 & 0.00 & 100 \\
\hline Simulation (3) & 0.00 & 0.00 & 3.52 & 96.48 & 0.00 & 0.00 & 0.00 & 0.00 & 0.00 & 0.00 & 100 \\
\hline Simulation (4) & 0.00 & 0.00 & 7.07 & 92.93 & 0.00 & 0.00 & 0.00 & 0.00 & 0.00 & 0.00 & 100 \\
\hline Simulation (5) & 0.00 & 0.00 & 5.63 & 94.37 & 0.00 & 0.00 & 0.00 & 0.00 & 0.00 & 0.00 & 100 \\
\hline Simulation (6) & 0.00 & 0.00 & 16.40 & 83.60 & 0.00 & 0.00 & 0.00 & 0.00 & 0.00 & 0.00 & 100 \\
\hline Simulation (7) & 0.00 & 2.02 & 27.40 & 70.58 & 0.00 & 0.00 & 0.00 & 0.00 & 0.00 & 0.00 & 100 \\
\hline Simulation (8) & 0.00 & 0.00 & 0.81 & 99.19 & 0.00 & 0.00 & 0.00 & 0.00 & 0.00 & 0.00 & 100 \\
\hline Simulation (9) & 0.00 & 0.00 & 3.36 & 96.64 & 0.00 & 0.00 & 0.00 & 0.00 & 0.00 & 0.00 & 100 \\
\hline Simulation (10) & 0.00 & 0.00 & 6.84 & 93.16 & 0.00 & 0.00 & 0.00 & 0.00 & 0.00 & 0.00 & 100 \\
\hline
\end{tabular}

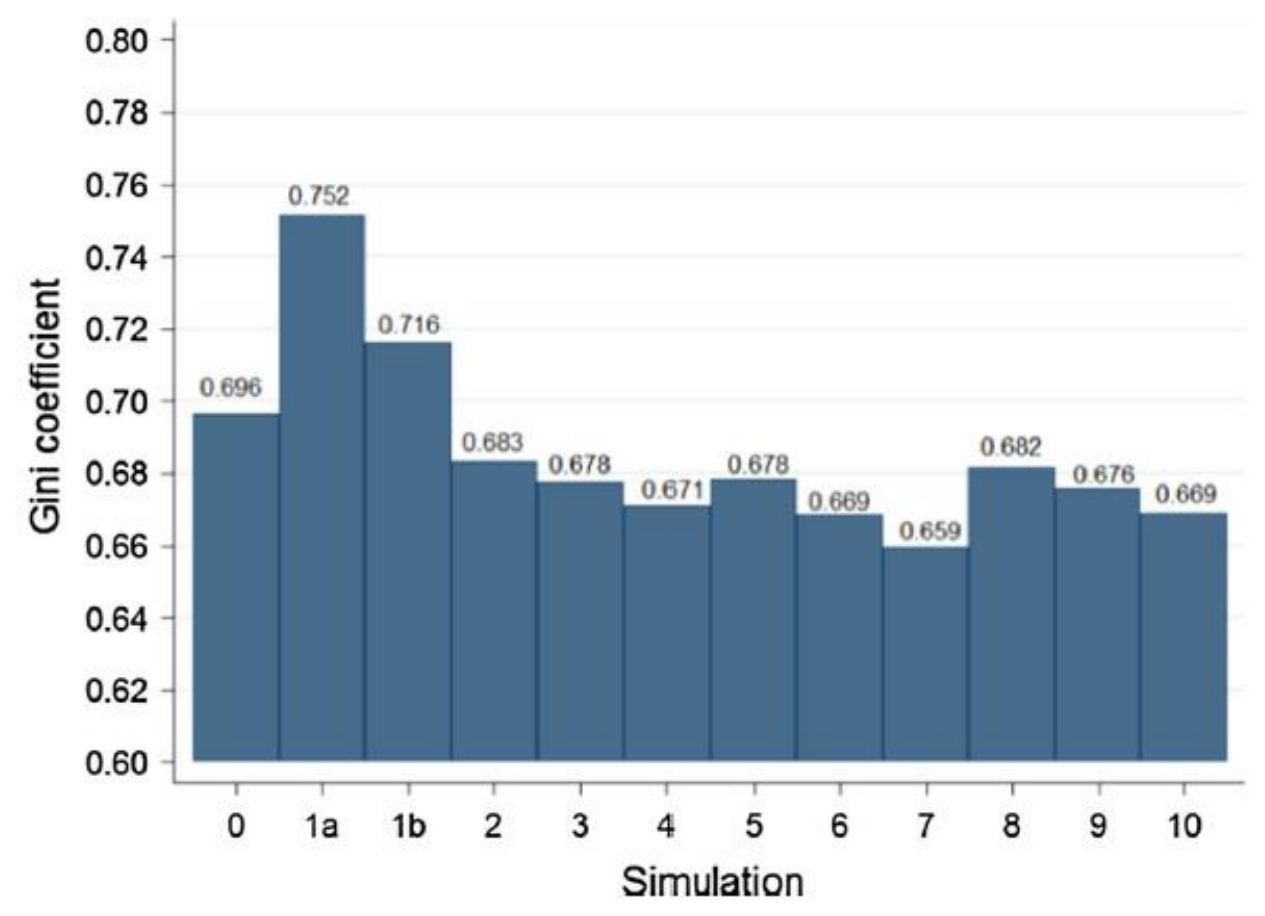

Fig. 4 Gini coefficient in each simulation. Source: Own calculations using IES 2010/11 data

\section{Conclusion}

The significance of CSG in alleviating poverty is well established in the literature. Our study contributes to the existing research by analysing in detail how changes in the eligibility criteria of this grant affect poverty and its fiscal implications. We also consider 
how inequality is affected. We ran several simulations that altered the age and income criteria as well as the monthly grant amount. Our findings showed that doubling the monthly grant (holding other criteria constant) resulted in the biggest decline in poverty and inequality. Even though the total additional social spending for this simulation was the second highest, in per capita terms it was the cheapest option since it moved the largest number of people out of poverty. It is possible that further increases in the monthly grant amount could have a negative impact on work effort (Black et al. 2015: 173), but one also has to account for the likely positive influence on education and nutrition (Coetzee 2013).

The fiscal implications of simulations (2)-(10) increase government spending, particularly in the case simulation (7). In per capita terms, it would be the most cost effective option of reducing poverty; in absolute terms, government spending would increase by approximately R47 billion. Social protection (which includes all social grants) along with education and health spending are amongst the top spending priorities of the South African government. Hence, it is probable that increases in the spending on the CSG would be accommodated. However, in the current context of fiscal austerity measures, such an increase might have to be financed by a reprioritisation of government spending.

\section{Appendix}

Table 5 Poverty gap and squared poverty gap ratios by race (poverty line: R7 175.52, 2011 March prices). Source Own calculations using IES 2010/11 data

\begin{tabular}{llllll}
\hline & All & Black & Coloured & Indian & White \\
\hline Poverty gap ratio & & & & & \\
Base income variable & 0.2483 & 0.2939 & 0.1140 & 0.0484 & 0.0404 \\
Simulation (1a) & 0.3929 & 0.4599 & 0.2139 & 0.0953 & 0.0714 \\
Simulation (1b) & 0.2990 & 0.3550 & 0.1382 & 0.0492 & 0.0409 \\
Simulation (2) & 0.2143 & 0.2535 & 0.0964 & 0.0414 & 0.0381 \\
Simulation (3) & 0.2002 & 0.2366 & 0.0895 & 0.0391 & 0.0376 \\
Simulation (4) & 0.1828 & 0.2158 & 0.0821 & 0.0366 & 0.0368 \\
Simulation (5) & 0.2015 & 0.2382 & 0.0905 & 0.0398 & 0.0379 \\
Simulation (6) & 0.1770 & 0.2087 & 0.0796 & 0.0368 & 0.0374 \\
Simulation (7) & 0.1544 & 0.1813 & 0.0700 & 0.0343 & 0.0369 \\
Simulation (8) & 0.2139 & 0.2531 & 0.0961 & 0.0414 & 0.0381 \\
Simulation (9) & 0.1998 & 0.2362 & 0.0893 & 0.0391 & 0.0376 \\
Simulation (10) & 0.1823 & 0.2152 & 0.0818 & 0.0366 & 0.0368 \\
\hline
\end{tabular}


Table 5 continued

\begin{tabular}{llllll}
\hline & All & Black & Coloured & Indian & White \\
\hline Squared poverty gap ratio & & & & & \\
Base income variable & 0.1643 & 0.1941 & 0.0685 & 0.0360 & 0.0355 \\
Simulation (1a) & 0.3375 & 0.3957 & 0.1721 & 0.0825 & 0.0658 \\
Simulation (1b) & 0.2241 & 0.2666 & 0.0937 & 0.0374 & 0.0357 \\
Simulation (2) & 0.1309 & 0.1540 & 0.0543 & 0.0292 & 0.0342 \\
Simulation (3) & 0.1176 & 0.1379 & 0.0490 & 0.0276 & 0.0336 \\
Simulation (4) & 0.1017 & 0.1187 & 0.0431 & 0.0258 & 0.0329 \\
Simulation (5) & 0.1194 & 0.1400 & 0.0498 & 0.0279 & 0.0340 \\
Simulation (6) & 0.0992 & 0.1156 & 0.0421 & 0.0255 & 0.0337 \\
Simulation (7) & 0.0827 & 0.0956 & 0.0358 & 0.0234 & 0.0334 \\
Simulation (8) & 0.1307 & 0.1538 & 0.0543 & 0.0292 & 0.0342 \\
Simulation (9) & 0.1174 & 0.1377 & 0.0490 & 0.0276 & 0.0336 \\
Simulation (10) & 0.1015 & 0.1184 & 0.0431 & 0.0258 & 0.0329 \\
\hline
\end{tabular}


Table 6 FGT poverty indices and the number of poor in each simulation, population 0-17 years only. Source Own calculations using the IES 2010/2011 data

\begin{tabular}{|c|c|c|c|c|}
\hline & Poverty headcount ratio & Poverty gap ratio & Squared poverty gap ratio & Number of poor \\
\hline \multicolumn{5}{|c|}{ Base income variable } \\
\hline All & 0.5678 & 0.3065 & 0.2010 & $10,753,551$ \\
\hline Black & 0.6357 & 0.3466 & 0.2281 & $10,212,473$ \\
\hline Coloured & 0.3031 & 0.1315 & 0.0784 & 457,237 \\
\hline Indian & 0.1395 & 0.0716 & 0.0491 & 48,386 \\
\hline White & 0.0348 & 0.0127 & 0.0082 & 35,417 \\
\hline \multicolumn{5}{|c|}{ Simulation (1a) } \\
\hline All & 0.6240 & 0.4708 & 0.4055 & $11,818,924$ \\
\hline Black & 0.6958 & 0.5305 & 0.4590 & $11,178,809$ \\
\hline Coloured & 0.3574 & 0.2221 & 0.1725 & 539,075 \\
\hline Indian & 0.1653 & 0.1078 & 0.0901 & 57,312 \\
\hline White & 0.0428 & 0.0220 & 0.0155 & 43,663 \\
\hline \multicolumn{5}{|c|}{ Simulation (1b) } \\
\hline All & 0.5946 & 0.3818 & 0.2920 & $11,261,332$ \\
\hline Black & 0.6655 & 0.4319 & 0.3317 & $10,691,705$ \\
\hline Coloured & 0.3214 & 0.1676 & 0.1157 & 484,798 \\
\hline Indian & 0.1395 & 0.0772 & 0.0547 & 48,386 \\
\hline White & 0.0357 & 0.0138 & 0.0087 & 36,335 \\
\hline \multicolumn{5}{|c|}{ Simulation (2) } \\
\hline All & 0.5381 & 0.2552 & 0.1502 & $10,191,223$ \\
\hline Black & 0.6049 & 0.2891 & 0.1706 & $9,718,461$ \\
\hline Coloured & 0.2698 & 0.1060 & 0.0572 & 407,033 \\
\hline Indian & 0.1278 & 0.0561 & 0.0359 & 44,335 \\
\hline White & 0.0209 & 0.0091 & 0.0061 & 21,332 \\
\hline
\end{tabular}


Table 6 continued

\section{Poverty headcount ratio Poverty gap ratio Squared poverty gap ratio Number of poor}

Simulation (3)

$\begin{array}{llllr}\text { All } & 0.5248 & 0.2342 & 0.1303 & 9,939,700 \\ \text { Black } & 0.5907 & 0.2654 & 0.1480 & 9,490,171 \\ \text { Coloured } & 0.2578 & 0.0962 & 0.0493 & 388,840 \\ \text { Indian } & 0.1253 & 0.0521 & 0.0335 & 43,447 \\ \text { White } & 0.0168 & 0.0081 & 0.0050 & 17,163\end{array}$

Simulation (4)

$\begin{array}{ll}\text { All } & 0.514 \\ \text { Black } & 0.5907 \\ \text { Coloured } & 0.257 \\ \text { Indian } & 0.125 \\ \text { White } & 0.016\end{array}$

0.2171

0.1150

$9,739,315$

0.2654

0.1480

$9,490,171$

0.0962

0.0493

388,840

0.0521

0.0335

43,447

0.0081

0.0050

17,163

Simulation (5)

All $\quad 0.5253$

Black $\quad 0.5912$

Coloured $\quad 0.2562$

Indian $\quad 0.1278$

White $\quad 0.0209$

Simulation (6)

All $\quad 0.4975$

Black $\quad 0.5610$

Coloured $\quad 0.2325$

Indian 0.1159

White $\quad 0.0189$

Simulation (7)

All $\quad 0.4636$

Black $\quad 0.5234$

Coloured $\quad 0.2140$

Indian $\quad 0.0870$

White $\quad 0.0173$

Simulation (8)

All $\quad 0.5363$

Black 0.6031

Coloured 0.2681

Indian $\quad 0.1278$

White $\quad 0.0209$

Simulation (9)

$\begin{array}{ll}\text { All } & 0.5230 \\ \text { Black } & 0.5887 \\ \text { Coloured } & 0.2560 \\ \text { Indian } & 0.1253 \\ \text { White } & 0.0168\end{array}$

Simulation (10)
$0.2362 \quad 0.1330$

0.2676

0.1509

0.0975

0.0521

0.0087

0.1997

0.2263

0.0821

0.0449

0.0079

0.1662

0.1882

0.0684

0.0399

0.0073

0.2547

0.2886

0.1057

0.0561

0.0091

0.2336

0.2648

0.0959

0.0521

0.1032

0.1170

0.0398

0.0287

0.0053

0.0793

0.0897

0.0311

0.0251

0.0049

0.1500

0.1703

0.0571

0.0359

0.0061
$22,033,407$

$20,620,166$

$1,042,531$

100,063

$2,70,566$

$9,422,260$

$9,012,225$

350,750

40,180

19,232

$8,779,626$

$8,408,968$

322,842

30,161

17,581

$10,158,267$

$9,688,258$

404,378

44,335

21,332

$9,904,661$

$9,457,719$

386,185

43,447

17,163 
Table 6 continued

\begin{tabular}{llllc}
\hline & Poverty headcount ratio & Poverty gap ratio & Squared poverty gap ratio & Number of poor \\
\hline All & 0.5124 & 0.2165 & 0.1146 & $9,704,276$ \\
Black & 0.5773 & 0.2453 & 0.1301 & $9,274,895$ \\
Coloured & 0.2445 & 0.0892 & 0.0440 & 368,822 \\
Indian & 0.1253 & 0.0503 & 0.0322 & 43,447 \\
White & 0.0168 & 0.0074 & 0.0044 & 17,163 \\
\hline
\end{tabular}

Table 7 Spending by function as proportion of total government expenditure, 2010/2011. Source Own calculations using the 2014/2015 budget review data (National Treasury 2014)

\begin{tabular}{llllll}
\hline & CSG (\%) & All grants (\%) & Social protection (\%) & Education (\%) & Health (\%) \\
\hline Base income variable & 3.8 & 10.9 & 11.7 & 21.3 & 12.6 \\
Simulation (2) & 5.7 & 12.6 & 13.4 & 20.9 & 12.4 \\
Simulation (3) & 6.4 & 13.3 & 14.1 & 20.7 & 12.3 \\
Simulation (4) & 7.4 & 14.2 & 15.0 & 20.5 & 12.1 \\
Simulation (5) & 6.4 & 13.3 & 14.1 & 20.7 & 12.3 \\
Simulation (6) & 7.8 & 14.6 & 15.3 & 20.4 & 12.1 \\
Simulation (7) & 9.1 & 15.8 & 16.6 & 20.1 & 11.9 \\
Simulation (8) & 7.2 & 14.0 & 14.8 & 20.5 & 12.2 \\
Simulation (9) & 8.2 & 15.0 & 15.8 & 20.3 & 12.0 \\
Simulation (10) & 9.6 & 16.2 & 17.0 & 20.0 & 11.9 \\
\hline
\end{tabular}




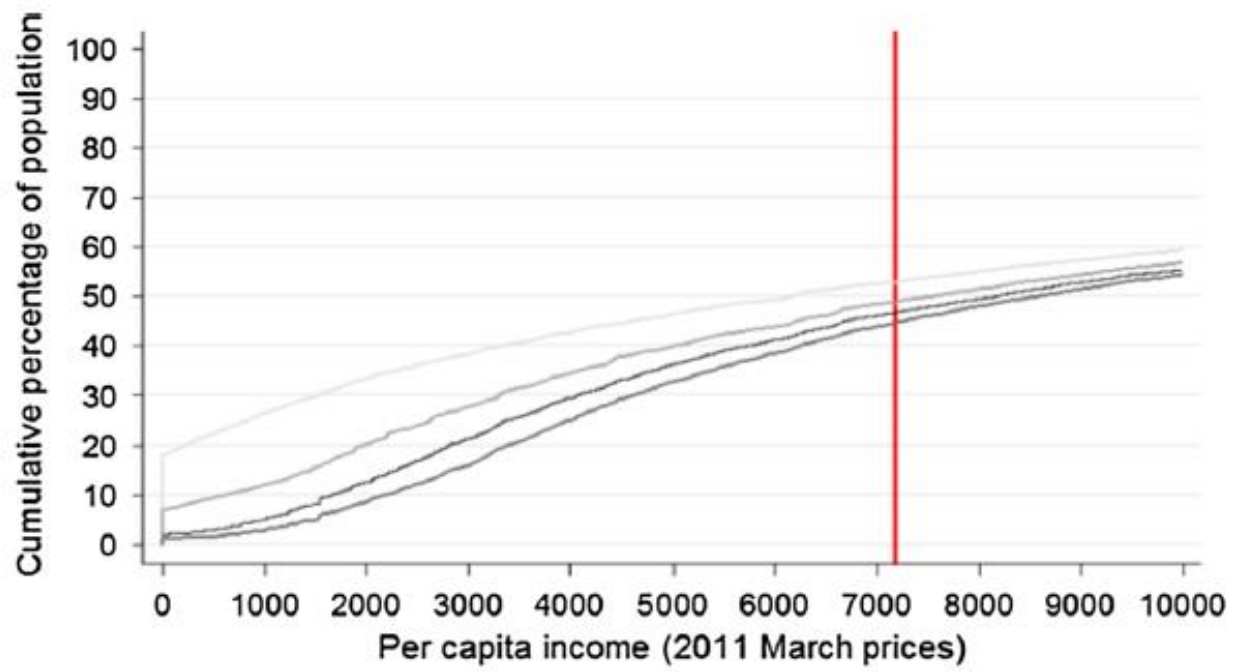

Per capita variable as it is Assuming zero social grant income Assuming zero CSG income

Age-eligible children receive CSG for full 12-month duration

Fig. 5 Cumulative density functions for simulations (1a), (1b) and (2). Source: Own calculations using IES $2010 / 11$ data

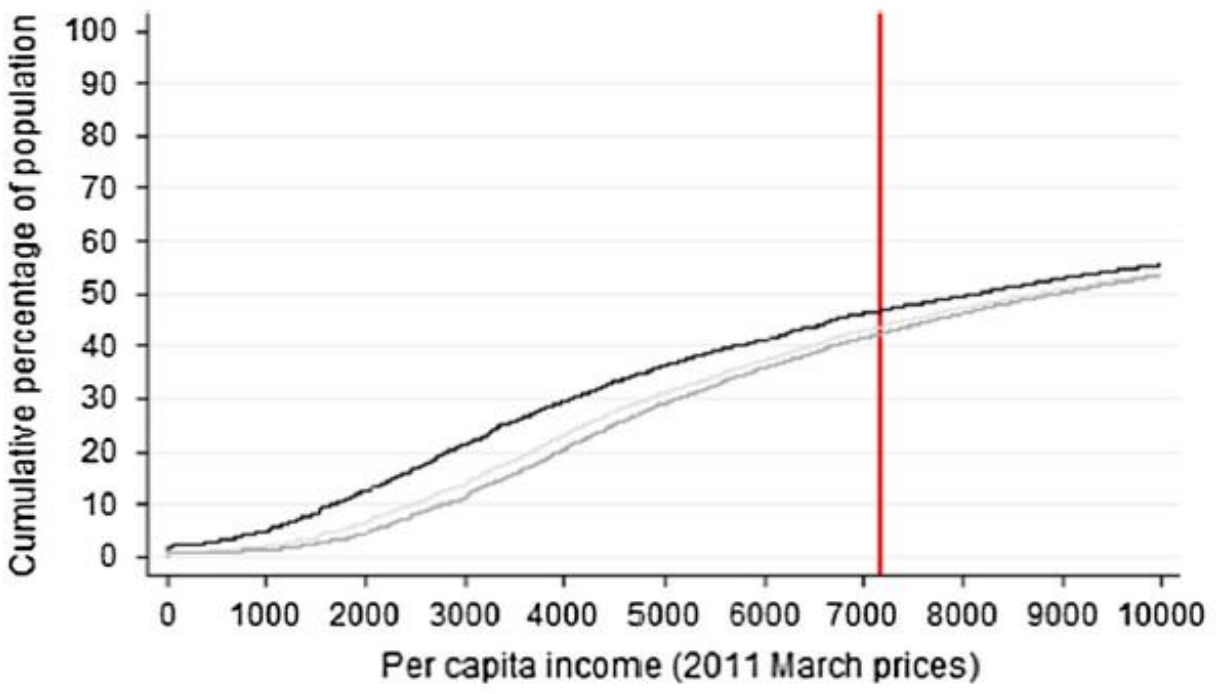

Per capita variable as it is 15-17 year old receive CSG 18-21 year old receive CSG

Fig. 6 Cumulative density functions for simulations (3) and (4). Source: Own calculations using IES 2010/11 data 


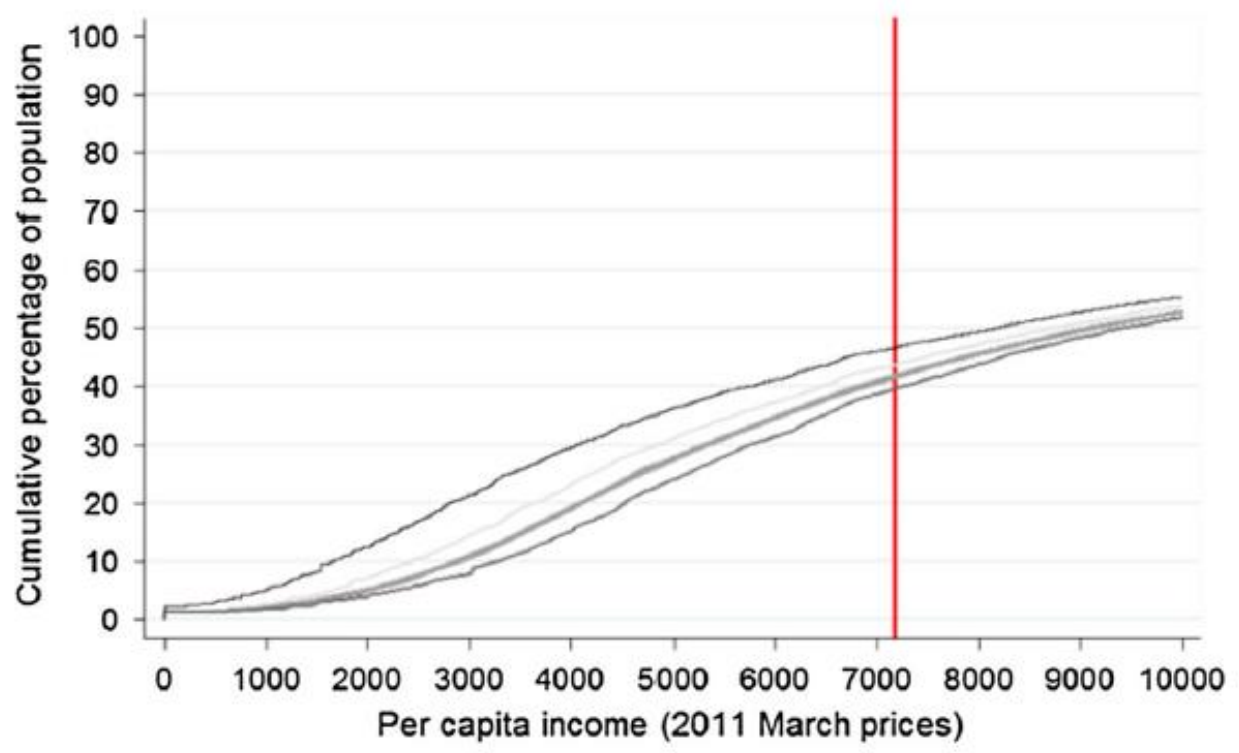

Per capita variable as it is

CSG monthly amount $=\mathbf{R} 300$

CSG monthly amount $=\mathrm{R} 400$

CSG monthly amount $=\mathbf{R} 500$

Fig. 7 Cumulative density functions for simulations (5)-(7). Source: Own calculations using IES 2010/11 data

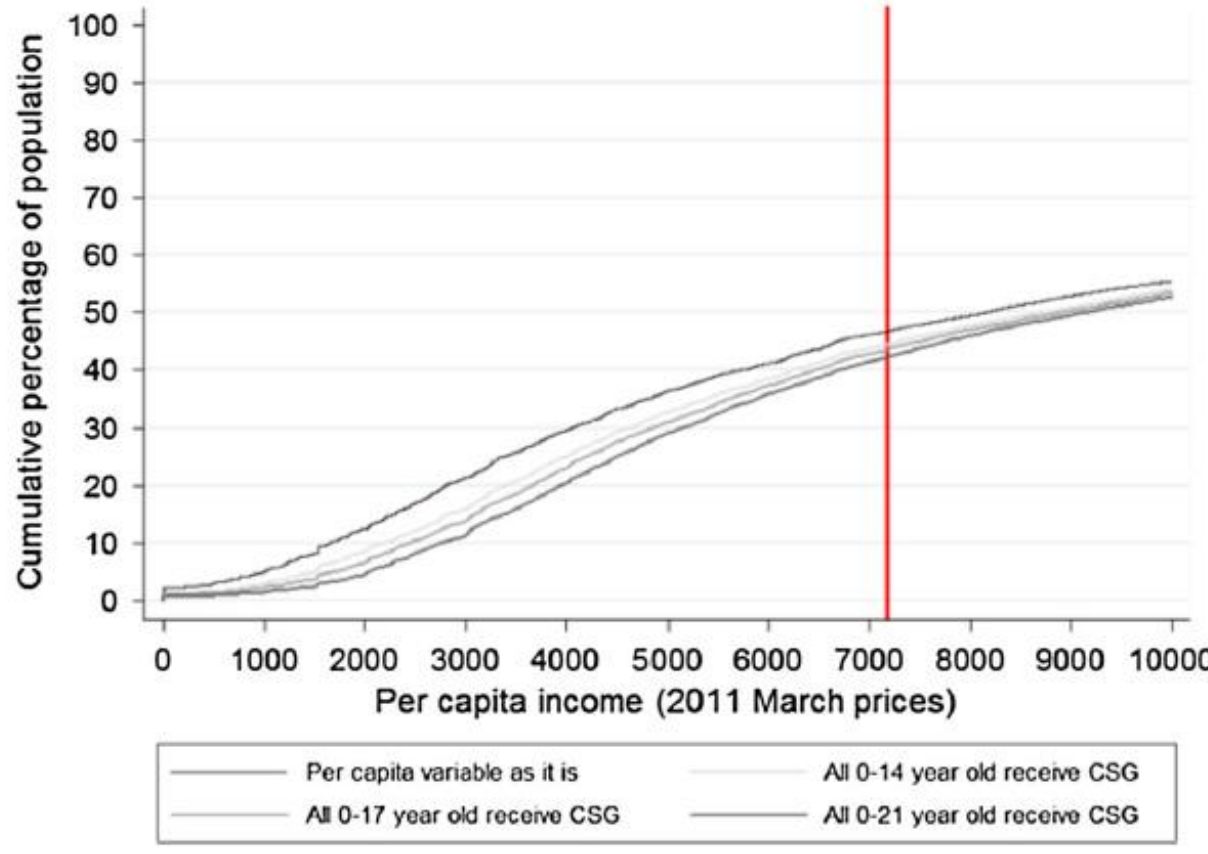

Fig. 8 Cumulative density functions for simulations (8)-(10). Source: Own calculations using IES 2010/11 data 


\section{References}

Aguero, J., Carter, M., \& Woolard, I. (2009). The impact of unconditional cash transfers on nutrition: The South African child support grant. In: IPC working paper 39. Brasilia: International Poverty Centre.

Armstrong, P., \& Burger, C. (2008). Poverty, inequality and the role of Social Grants: An analysis through decomposition techniques. Paper presented at the Development Policy Research Unit Conference.

Bhorat, H., Tseng, D., \& Stanwix, B. (2014). Pro-poor growth and social protection in South Africa: Exploring the interactions. Development Southern Africa, 31(2), 219240.

Black, P., Calitz, E., \& Steenekamp, T. (2015). Public Economics (6th ed.). Cape Town: Oxford University Press.

Black Sash: Making Human Rights Real. (2015). You and your rights: Child support grant. http://www. blacksash.org.za/images/yourrights/csg_june05.pdf. Accessed July 20, 2015 .

Budlender, D., \& Woolard, I. (2006). The impact of the South African child support and old age grants on children's schooling and work. Unpublished study prepared for the international programme on the elimination of child labour. Geneva: International Labour Organisation.

Case, A., Hosegood, V., \& Lund, F. (2005). The reach and impact of child support grants: Evidence from KwaZulu-Natal. Development Southern Africa, 22(4), 467-482.

Coetzee, M. (2013). Finding the benefits: Estimating the impact of the South African child support grant. South African Journal of Economics, 81(3), 427-450.

Devereux, S. (2007). Social pensions in Southern Africa in the twentieth century. Journal of Southern African Studies, 33(3), 539-560.

Devereux, S., Masset, E., Sabates-Wheeler, R., Samson, M., Rivas, A.-M. \& Te Lintelo, D. (2015). Evaluating the targeting effectiveness of social transfers: A literature review. In: CSP working paper No. 012. Brighton: Centre for the Social Protection.

Fin24. (2015). R3.3bn plan to extend child support grant to 21. http://www.fin24.com/Economy/R33bn-child-care-grant-extension-to-21-on-cards20150316. Accessed August 7, 2015.

Gomersall, J. (2013). The performance of the child support grant: Review and research priorities. Development Southern Africa, 30(4-5), 525-544.

Hall, K. (2014). Income and social grants-child support grants. http://www.childrencount.ci.org.za/ indicator.php?id=2\&indicator=10. Accessed July $20,2015$.

Leibbrandt, M., Finn, A., \& Woolard, I. (2012). Describing and decomposing postapartheid income inequality in South Africa. Development Southern Africa, 29(1), 19-34.

Leibbrandt, M., Woolard, I., Finn, A., \& Argent, J. (2010). Trend in South African income distribution and poverty since the fall of apartheid. In: OECD social, employment and migration working papers No. 101. Paris: Organisation for Economic Co-operation and Development. 
Levine, S., Van der Berg, S., \& Yu, D. (2011). The impact of cash transfers on household welfare in Namibia. Development Southern Africa, 28(1), 39-59.

McEwen, H., \& Woolard, I. (2008). The changing dynamics of child grants in the context of high adult mortality in South Africa: A simulation to 2015. Published study for the Institute for Poverty, Land and Agrarian Studies (PLAAS). http://www.plaas.org.za/sites/default/files/publications-pdf/Woolard_ McEwen.pdf. Accessed May 21, 2016.

National Treasury. (2013). National Budget 2013: Chapter 6: Social security and the social wage. Pretoria: National Treasury.

National Treasury. (2014). Estimates of national expenditure 2014. Pretoria: National Treasury.

Omiolola, B., \& Kaniki, S. (2014). Social protection in Africa: A review of potential contribution and impact on poverty reduction. New York: United Nations Development Programme (UNDP).

Osei, R. D. (2011). Reducing poverty through a social grants programme: The case of Ghana. Institute of Statistical Social and Economic Research (ISSER). Legon: University of Ghana.

Republic of South Africa. (2015). Child support grant. http://www.gov.za/services/child-care-social-benefits/child-support-grant. Accessed November 08, 2015.

Rosa, S., \& Guthrie, T. (2002). Extending the child support grant to all children under 18 years. http://www. ci.org.za/depts/ci/pubs/pdf/rights/facts/csg_final.pdf. Accessed May 25, 2016.

Rosen, H. S., \& Gayer, T. (2014). Public finance (10th ed.). New York: McGraw-Hill Higher Education. South African Social Security Agency (SASSA). (2010). You and your grants 2010/2011. http://www.downsyndrome.org.za/SASSA.pdf. Accessed July 20, 2015 .

Statistics South Africa. (2012). Income and expenditure of households 2010/2011: Metadata. Pretoria: Statistics South Africa.

Statistics South Africa. (2015). CPI history: 1960 onwards. http://www.statssa.gov.za/publications/Po141/ CPIHistory.pdf. Accessed July 20, 2015 .

Triegaardt, J. D. (2005). The child support grant in South Africa: A social policy for poverty alleviation? International Journal of Social Welfare, 14, 249-255.

Van der Berg, S., Louw, M., \& Du Toit, L. (2009). Poverty trends since the transition: What we know. In: Stellenbosch economic working papers: 19/09. Stellenbosch: Stellenbosch University.

Van der Berg, S., Siebrits, K., \& Lekezwa, B. (2010). Efficiency and equity effects of social grants in South Africa. In: Stellenbosch economic working papers No 15/10. Stellenbosch: University of Stellenbosch, Department of Economics and Bureau for Economic Research.

Woolard, I., \& Leibbrandt, M.V. (2006). Towards a poverty line for South Africa: Background note. 
Southern Africa Labour and Development Research Unit (SALDRU), University of Cape Town. Woolard, I., Buthelezi, T., \& Bertscher, J. (2012). Child grants: Analysis of the NIDS Wave 1 and 2 Datasets. In: SALDRU working paper series No. 84/NIDS discussion paper 2012/7. Cape Town: Southern African Labour and Development Research Unit.

World Bank. (2013). World development report 2014: Risk and opportunity. Washington: World Bank.

Wright, G., Neves, D., Ntshongwana, P., \& Noble, M. (2015). Social assistance and dignity: South African women's experiences of the child support grant. Development Southern Africa, 32(4), 443-457. 